\title{
IDENTIFIKASI METABOLIT SEKUNDER DAN PENGUJIAN TOKSISITAS EKSTRAK METANOL KULIT KAYU LABAN (Vitex pinnata L.) DENGAN METODE BRINE SHRIMP LETHALITY TEST (BSLT)
}

\author{
Florensius Rinaldi F*, Arsyik Ibrahim, Jaka Fadraersada, Laode Rijai \\ Laboratorium Penelitian dan Pengembangan FARMAKA TROPIS \\ Fakultas Farmasi, Universitas Mulawarman, \\ Samarinda, Kalimantan Timur \\ *email : florensius.rf@gmail.com
}

\begin{abstract}
ABSTRAK
Laban (Vitex pinnata) merupakan salah satu tanaman tradisional yang sering digunakan oleh masyarakat dayak, untuk menyembuhkan diare dan disenteri Dalam penelitian ini digunakan bagian kulit kayunya sebagai sampel. Telah dilakukan penelitian yang bertujuan untuk menghitung nilai rendemen, mengidentifikasi senyawa aktif dan analisis toksisitas dari kulit kayu laban dengan menggunakan metode Brine Shrimp Lethality Test (BSLT) dengan menggunakan larva udang Artemia salina L. sebagai bioindikator. Penelitian ini dimulai dari ekstraksi kulit kayu laban (Vitex pinnata) dengan metode refluks, dengan pelarut metanol. Ekstrak metanol kemudian dipekatkan, lalu dihitung nilai rendemen, dilakukan uji fitokimia dan uji toksisitas. Dari proses ekstraksi, diketahui bahwa nilai rendemen ekstrak metanol kulit kayu laban (Vitex pinnata) adalah sebesar 17\%. Dari uji metabolit sekunder, diperoleh data bahwa ekstrak kulit kayu laban positif mengandung flavonoid, tanin dan senyawa fenolik. Dari hasil uji toksisitas diperoleh bahwa ekstrak metanol kulit kayu laban memiliki nilai toksisitas sebesar 177 ppm. Dari nilai LC $_{50}$ ini, diduga bahwa ekstrak metanol kulit kayu laban (Vitex pinnata) memiliki aktivitas sebagai antimikroba.
\end{abstract}

Kata kunci : Antimikroba, BSLT, Refluks, Uji Fitokimia, Vitex pinnata.

\begin{abstract}
Round Leaf Chaste Tree (Vitex pinnata) is one of herbal medicines that often used by Dayak tribe, to cure diarrhea and dysentery. In this research, the part of the plant that used is the bark of a tree as a sample. The research has been conducted with aims to count yield value, identify the active compounds and toxicity analysis from the sample's extract using Brine Shrimp Lethality Test (BSLT) method, and using Artemia salina L shrimp larvae as a bioindicator. It starts from the extraction of the bark Laban with reflux method, with methanol as a solvent. Then the methanol extract is concentrated, and the extract is used in pytochemistry test and toxicity test. From the extraction process, it is showed that yield value of the extract is $17 \%$, from pytochemistry test is showed that the extract contains flavonoids, tannins and phenolic compounds. From the results of toxicity tests showed that the methanol extract has toxicity value, which is $177 \mathrm{ppm}$. From the $L C_{50}$ value is presumed that the methanol extract have activity as antimicrobial.
\end{abstract}

Key words : Antimicrobial, BSLT, Phytochemistry Test, Reflux, Vitex pinnata. 


\title{
PENDAHULUAN
}

Tumbuhan Vitex pinnata L. banyak terdapat di Kalimantan Timur. Merupakan pohon cemara berukuran kecil hingga sedang dengan tinggi 25 - 30 meter Tanaman Laban tumbuh pada dataran rendah sampai ketinggian $\pm 800 \mathrm{~m}$ dpl. Biasanya tumbuh baik di hutan sekunder, hutan jati, di tepi sungai dan sepanjang jalan Daun dan kulit kayu digunakan untuk mengobati diare, disentri, demam dan malaria. Orang Dayak Tunjung biasa menggunakan daun dan kulit kayu laban ini secara tradisional digunakan untuk mengobati diare dan disentri serta untuk membantu menyembuhkan luka. Kulit kayunya selain untuk obat juga digunakan sebagai medium penanaman anggrek.

Telah dilakukan uji perhitungan rendemen untuk mengetahui persentasi rendemen ekstrak metanol kulit kayu Laban yang diperoleh dari proses ekstraksi. Dilanjutkan dengan pengujian fitokimia dengan tujuan untuk mengetahui golongan metabolit sekunder apa saja yang terkandung di dalam ekstrak metanol kulit kayu Laban, dan dilakukan uji toksisitas pada ekstrak kulit kayu Laban dengan metode BSLT, dimana larva udang Artemia salina L. diuji terhadap variasi konsentrasi ekstrak kulit kayu laban untuk mengetahui kemampuan ekstrak dalam membunuh larva udang Artemia salina L. yang diujikan. Menurut (Cahyadi, 2012), ada 3 tingkat toksisitas menurut nilai $\mathrm{LC}_{50}$ yang diperoleh. Senyawa dinyatakan tidak toksik apabila nilai $\mathrm{LC}_{50}$ senyawa tersebut berada diatas $1000 \mathrm{ppm}$. Senyawa dinyatakan memiliki toksisitas rendah, apabila nilai $\mathrm{LC}_{50}$ senyawa tersebut berada pada kisaran $200 \mathrm{ppm}$ - 1000 ppm. Pada kedua rentang konsentrasi tersebut diduga memiliki aktivitas sebagai desinfektan. Senyawa dinyatakan memiliki tingkat toksisitas menengah apabila nilai $\mathrm{LC}_{50}$ senyawa tersebut berada pada kisaran 30 ppm - 200 ppm, dan diduga memiliki aktivitas antimikroba. Dan suatu senyawa dinyatakan memiliki toksisitas tinggi apabila nilai $\mathrm{LC}_{50}$ senyawa tersebut dibawah 30 ppm dan diduga memiliki aktivitas antikanker.

\section{METODE PENELITIAN Bahan}

Bahan yang diteliti adalah kulit kayu laban (Vitex pinnata). Pelarut yang digunakan dalam proses ekstraksi adalah pelarut metanol. Aquades digunakan untuk melarutkan ekstrak. DMSO digunakan untuk membantu melarutkan ekstrak dalam aquades. Serta reagen - reagen khusus yang digunakan dalam pengujian fitokimia ekstrak.

\begin{abstract}
Alat
Peralatan yang digunakan dalam penelitian ini yaitu serangkaian alat refluks, rotary evaporator, cawan porselen, tabung reaksi, rak tabung reaksi, timbangan analitik, botol vial, dan alat penunjang lainnya.

\section{Prosedur Penelitian \\ Pengambilan Sampel}

Kulit kayu laban yang digunakan diambil dari batang dan cabang utama dengan cara disayat dari bagian kulit luar ke dalam batang sedalam 1-2 cm. Hasil sayatan kulit kemudian dicuci dengan air mengalir dan dipisah kulit kayu bagian dalam dari kulit luarnya. Bagian kulit kayu dalam kemudian dirajang, lalu dikeringkan dengan cara diangin - anginkan di udara terbuka pada tempat yang terlindung sinar matahari. Simplisia yang diperoleh kemudian ditimbang sebagai data untuk perhitungan rendemen.
\end{abstract}

\section{Ekstraksi}

Potongan kecil kulit kayu laban diekstraksi dengan metode refluks selama $3-4$ jam. Dari ekstraksi tersebut diperoleh residu dan larutan ekstrak metanol kulit kayu laban. Kemudian disaring dan residu disisihkan. Dan bagian cair ekstrak di dipekatkan dengan rotary evaporator, hingga diperoleh ekstrak kental, lalu ekstrak diuapkan diatas water bath 
untuk menghilangkan sisa pelarut. Untuk memperoleh ekstrak kering. Sebelum digunakan, ekstrak diuji bebas pelarut untuk mengetahui apakah ekstrak yang diperoleh masih mengandung pelarut atau tidak

\section{Uji Fitokimia Ekstrak}

\section{Identifikasi Senyawa Triterpenoid dan Steroid}

Larutan ekstrak ditambah asam asetat anhidrat hingga zat terendam lalu dibiarkan 15 menit. Ditambahkan 1 tetes larutan asam sulfat pekat. Diamati perubahan warna. Apabila terbentuk warna hijau biru maka hasil positif untuk steroid, dan bila terbentuk warna ungu maka hasil positif untuk triterpenoid.

\section{Identifikasi Senyawa Alkaloid}

Sebanyak $2 \mathrm{ml}$ ekstrak ditambahkan $1,5 \mathrm{ml}$ asam klorida 2\%. Larutan kemudian dibagi dalam 3 tabung reaksi. Tabung 1 sebagai pembanding, tabung 2 ditambahkan pereaksi Meyer, dan tabung 3 ditambahkan pereaksi Dragendorff. Adanya alkaloid ditunjukkan dengan adanya kekeruhan atau endapan putih kekuningan pada penambahan pereaksi Meyer, dan endapan jingga kecoklatan pada penambahan pereaksi Dragendorff.

\section{Identifikasi Senyawa Flavonoid}

Ekstrak yang diperoleh dilarutkan dengan bantuan pemanasan. Pada larutan ditambahkan logam magnesium dan 4-5 tetes asam klorida pekat. Adanya aglikon flavonoid ditunjukkan dengan adanya perubahan warna menjadi merah atau jingga.

\section{Identifikasi Senyawa Fenolik}

Sebanyak $2 \mathrm{ml}$ ekstrak ditambah 3 tetes $\mathrm{FeCl}_{3}$. Terbentuknya larutan hijau atau biru hingga kehitaman menunjukkan adanya senyawa fenolik.

\section{Identifikasi Senyawa Saponin}

Larutan ekstrak dididihkan dalam penangas air selam 5 menit. Begitu dingin kemudian disaring. Filtrat dikocok kuat secara vertikal selama 1-2 menit. Adanya senyawa saponin dapat ditunjukkan dengan adanya busa yang terbentuk setinggi $1 \mathrm{~cm}$ yang stabil setelah dibiarkan selama 1 jam. Atau pada penambahan 1 tetes HCL 0,1 N.

\section{Identifikasi Senyawa Tanin}

Larutan ekstrak ditambahkan gelatin $1 \%$ ke dalam tabung reaksi. Hasil positif ditandai dengan terbentuknya endapan putih.

\section{Pengujian Toksisitas Ekstrak dengan Metode BSLT}

Telur larva udang Artemia salina L. di tetaskan dalam media air laut dengan pencahayaan lampu pijar. Penetasan telur akan memakan waktu selama 48 jam. Dibuat larutan stok dan larutan seri konsentrasi ekstrak, yaitu konsentrasi 30, 60, 90, dan 120 ppm, dimana ekstrak dilarutkan di dalam air laut dan dapat ditambahkan DMSO bila perlu untuk membantu melarutkan ekstrak. Larutan seri konsentrasi kemudian dimasukkan ke dalam botol vial, dimana pada setiap seri konsentrasi dimasukkan ke dalam 5 botol vial berbeda. Larva udang yang telah menetas kemudian dimasukkan ke dalam botol vial yang berisi larutan ekstrak, dengan jumlah 10 larva di setiap botol vial. Larva udang kemudian diberikan larutan ragi sebagai makanan. Setelah itu dibiarkan selama 24 jam, dan dihitung jumlah larva udang yang hidup dan larva udang yang mati lalu dilakukan analisis data secara probit untuk menentukan nilai $\mathrm{LC}_{50}$.

\section{HASIL DAN PEMBAHASAN \\ Perhutungan Nilai Rendemen Ekstrak}

Hasil dari proses pembuatan simplisia dan proses ekstraksi diperoleh data rendemen. Rendemen dari sampel segar menjadi simplisia, ekstraksi simplisia secara refluks, diperoleh data yang dapat dilihat pada tabel 1 : 
Tabel 1. Data Rendemen Ekstrak Kulit Kayu Laban

\begin{tabular}{ccccc}
\hline $\begin{array}{l}\text { Bobot Ekstrak } \\
\text { Kering (gram) }\end{array}$ & $\begin{array}{c}\text { Bobot Sampel } \\
\text { Segar (gram) }\end{array}$ & $\begin{array}{c}\text { Bobot } \\
\text { Simplisia } \\
\text { Kering (gram) }\end{array}$ & $\begin{array}{c}\text { Nilai } \\
\text { Rendemen 1 } \\
(\%)\end{array}$ & $\begin{array}{c}\text { Nilai } \\
\text { Rendemen 2** } \\
(\%)\end{array}$ \\
\hline \multirow{2}{*}{30} & 3750 & 175 & 0,008 & 17 \\
\cline { 2 - 5 }
\end{tabular}

* : Rendemen I : rendemen ditinjau dari sampel segar

** : Rendemen II: rendemen ditinjau dari sampel kering (simplisia)

Penelitian dimulai dari proses ekstraksi simplisia kulit kayu Laban dengan metode refluks. Alasan penggunaan metode ini adalah karena bila menggunakan ekstraksi cara dingin seperti maserasi dikhawatirkan senyawa - senyawa yang ada dalam simplisia tidak akan terekstraksi secara maksimal, selain itu ekstraksi refluks umumnya tidak memakan waktu lama bila dibandingkan dengan maserasi. Selain itu, menurut (Wewengkang, 2011), senyawa yang terdapat didalam kulit kayu dapat terekstraksi secara optimal dengan bantuan panas. Sehingga alasan inilah mengapa digunakan metode refluks. Dari proses ekstraksi dan evaporasi diperoleh ekstrak kering dengan bobot ekstrak seberat 30 gram. Bila dibandingkan dengan bobot simplisia kulit kayu laban sebesar 175 gram, maka diperoleh data bahwa rendemen ekstrak ekstrak metanol kulit kayu laban adalah sebesar 17\%, dan didapat pula nilai rendemen $0,008 \%$ bila dibandingkan dengan sampel segar dengan bobot 3750 gram.

\section{Uji Fitokimia Ekstrak}

Berdasarkan hasil uji fitokimia terhadap ekstrak metanol kulit kayu laban diperoleh data yang dapat dilihat pada tabel 2. Hasil dari uji fitokimia ekstrak menunjukkan bahwa ekstrak positif mengandung golongan senyawa fenolik, flavonoid, dan tanin.

Tabel 2. Uji Fitokimia Ekstrak Metanol Kulit Kayu Laban

\begin{tabular}{ccc}
\hline No. & $\begin{array}{c}\text { Golongan metabolit } \\
\text { sekunder }\end{array}$ & Hasil \\
\hline 1 & Alkaloid & $(-)$ \\
2 & Fenolik & $(+)$ \\
3 & Flavonoid & $(+)$ \\
4 & Saponin & $(-)$ \\
5 & Steroid/Triterpenoid & $(-)$ \\
6 & Tanin & $(+)$ \\
\hline
\end{tabular}

Keterangan:

(+) : Teridentifikasi golongan metabolit sekunder

(-) : Tidak teridentifikasi golongan metabolit sekunder 


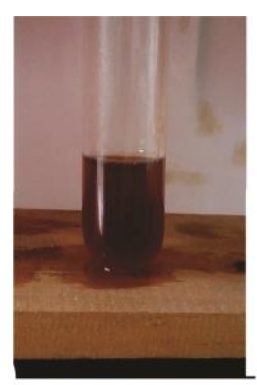

(a)

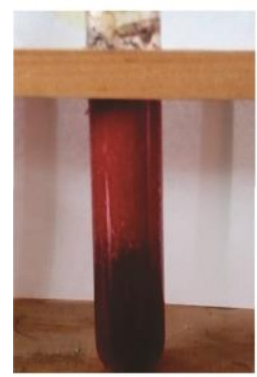

(d)

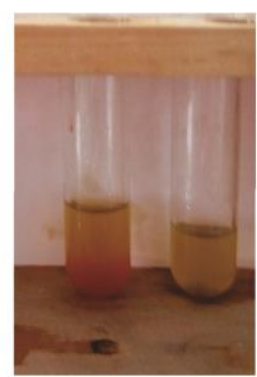

(b)

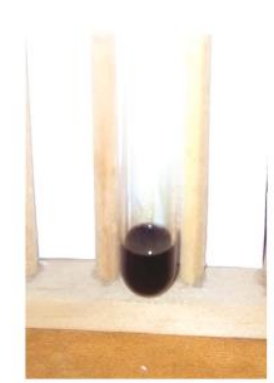

(e)

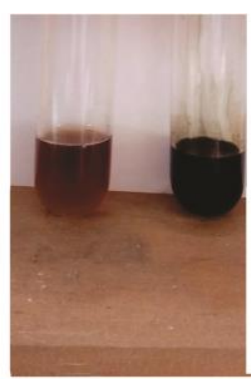

(c)

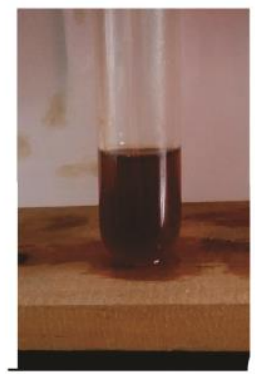

(f)

Gambar 1. Hasil Uji Fitokimia Ekstrak Metanol Kulit Kayu Laban. (a) Saponin (b) Alkaloid (c) Tanin (d) Flavonoid (e) Fenolik (f) Steroid/Triterpenoid

Dari hasil pengujian, diketahui bahwa ekstrak metanol kulit kayu laban positif mengandung golongan senyawa fenolik, flavonoid dan tanin. Terdapat beberapa masalah dalam uji fitokimia ini, diantaranya adalah adanya hasil positif palsu pada pengujian alkaloid. Hal - hal tersebut dapat ditanggulangi, dimana pada alkaloid dapat dilakukan pengujian ulang, hingga didapat hasil yang sama pada 3 kali pengujian berturut - turut. Pada uji saponin diperoleh hasil bahwa ekstrak tidak mengandung saponin. Hal ini dibuktikan dengan tidak terbentuknya busa pada larutan yang sudah dikocok kuat. Dan pada uji steroid/triterpenoid diperoleh hasil bahwa ekstrak tidak mengandung baik golongan senyawa steroid, maupun golongan senyawa triterpenoid. Hal ini dibuktikan dengan tidak berubahnya warna larutan menjadi hijau atau biru yang menandakan ekstrak positif mengandung steroid, ataupun berubah warna menjadi ungu yang menandakan ekstrak positif mengandung triterpenoid.

\section{Pengujian Toksisitas dengan Metode BSLT}

Jumlah dan persentasi kematian larva udang dapat dilihat di tabel 3.

Tabel 3. Tabel Uji BSLT Ekstrak Metanol Kulit Kayu Laban

\begin{tabular}{cccccccc}
\hline Sampel & $\begin{array}{c}\text { Konsentra } \\
\text { si (ppm) }\end{array}$ & $\begin{array}{c}\text { Log } \\
\text { Konsentrasi }\end{array}$ & Hidup & Mati & $\begin{array}{c}\% \\
\text { kematian }\end{array}$ & $\begin{array}{c}\text { Harga } \\
\text { Probit }\end{array}$ & LC $_{50}(\mathrm{ppm})$ \\
\hline \multirow{3}{*}{ Ekstrak } & 30 & 1,48 & 27 & 3 & 10 & 3,72 & \\
Metanol & 60 & 1,78 & 24 & 6 & 20 & 4,16 & 177 \\
& 90 & 1,95 & 21 & 9 & 30 & 4,48 & \\
& 120 & 2,08 & 18 & 12 & 40 & 4,75 & \\
\hline
\end{tabular}




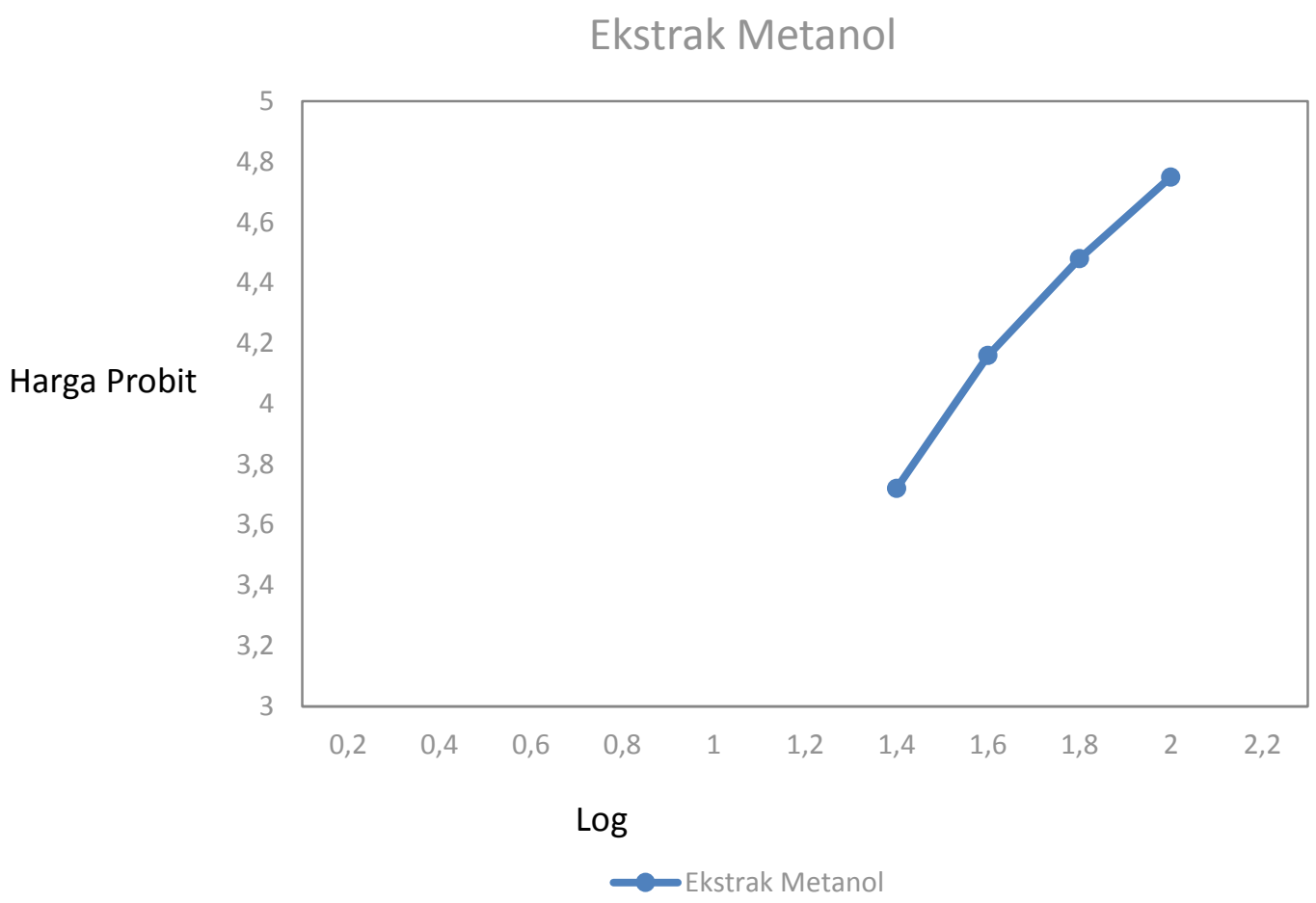

Gambar 2. Grafik Uji BSLT Ekstrak Kulit Kayu Laban

Uji BSLT dilakukan dengan menggunakan bioindikator larva udang Artemia salina Leach. Data yang digunakan diperoleh dari jumlah kematian larva yang diambil adalah 3 replikasi terbaik pada setiap konsentrasi, dengan kata lain pada setiap konsentrasi diambil 3 botol vial berisi larva udang yang memiliki selisih jumlah kematian paling dekat antara satu replikasi dengan replikasi yang lainnya. Lalu dihitung persentase kematian di setiap konsentrasi lalu dianalisis data yang diperoleh dengan metode probit.

Dari analisis data dengan menggunakan analisis probit, diperoleh hasil bahwa nilai $\mathrm{LC}_{50}$ ekstrak metanol kulit kayu laban adalah sebesar $177 \mathrm{ppm}$. Dengan nilai yang diperoleh, diduga bahwa ekstrak metanol kulit kayu laban memiliki tingkat toksisitas menengah dengan dugaan memiliki aktivitas sebagai antimikroba.

Golongan metabolit sekunder yang aktif dalam pengujian ini adalah senyawa fenolik, flavonoid, dan tanin. Golongan - golongan senyawa tersebut bekerja membunuh larva udang dengan cara menghambat kemampuan larva udang untuk makan. Dalam hal ini saluran pencernaan larva udang dirusak oleh golongan - golongan senyawa tersebut. Membuat larva udang tidak dapat merasakan makanannya, sehingga larva udang mati karena kelaparan.

Golongan - golongan senyawa tersebut memiliki mekanisme yang berbeda dalam membunuh mikroba. Mekanisme kerja flavonoid sebagai antibakteri adalah membentuk senyawa kompleks dengan protein ekstraseluler dan terlarut sehingga dapat merusak membran sel bakteri dan diikuti dengan keluarnya senyawa intraseluler. Mekanisme kerja tanin sebagai antibakteri adalah menghambat enzim reverse transkriptase dan DNA topoisomerase sehingga sel bakteri tidak dapat terbentuk. Dan mekanisme antimikroba senyawa fenolik adalah dengan merusak lipid pada membran plasma mikroorganisme sehingga menyebabkan isi sel keluar 


\section{KESIMPULAN}

Ekstrak metanol kulit kayu laban memiliki nilai rendemen sebesar 17\% terhadap bobot simplisia, mengandung golongan metabolit sekunder senyawa fenolik, flavonoid, dan tanin. Dari uji BSLT terhadap larva udang Artemia salina L. didapat hasil bahwa ekstrak metanol kulit kayu laban memiliki tingkat toksisitas menengah, dengan nilai $\mathrm{LC}_{50}$ sebesar 177 ppm, dengan dugaan bahwa ekstrak metanol kulit kayu laban memiliki aktivitas sebagai antimikroba

\section{DAFTAR PUSTAKA}

Cahyadi, Robby. 2011. Acute Toxicity Test of Bitter Melon Fruit (Momordica charantia) Extract against Artemia salina Leach Larvae using Brine Shrimp Lethality Test (BSLT). Universitas Diponegoro : Semarang.

Marliana, E. dan Pasaribu, M. 2007. Aktivitas Antioksidan Ekstrak Etanol Daun Vitex pinnata L. terhadap Radikal 2,2-diphenyl-1-picrylhydrazyl. Jurnal Kimia Mulawarman. 9 (1):4-6.

Reveny, Julia. 2011. Daya Antimikroba Ekstrak dan Fraksi Daun Sirih Merah (Piper betle Linn.). Universitas Sumatera Utara: Medan.

Ruwaida, D.G. 2010. Uji Toksisitas Senyawa Hasil Isolasi Rumput Mutiara

(Hedyotis corymbosa (L.)Lamk.) dengan Metode Brine Shrimp Lethality Test (BSLT). Universitas Sebelas Maret : Surakarta.

Tenmozhi, S \& Subasini U. 2016. Morpho-anatomical and Psychochemical Evaluation of Vitex pinnata linn Leaves. European Journal of Biomedical and Pharmaceutical Sciences. 3 (4) 483 - 492.

Wewengkang, Defny. 2014. Aktivitas Antioksidan dari Ekstrak Fenolik Korteks Umbi Ubi Kayu (Manihot esculenta) Daging Putih \& Kuning. Universitas Sam Ratulangi : Manado. 